\title{
Synthesis and antimicrobial activity of ciprofloxacin and norfloxacin permanently bonded to polyethylene glycol by a thiourea linker
}

\author{
Gábor Pintér ${ }^{1}$, Pál Horváth ${ }^{1}$, Sándor Bujdosó ${ }^{1}$, Ferenc Sztaricskai ${ }^{1}$, Sándor Kéki ${ }^{2}$, Miklós Zsuga $^{2}$, \\ Szilvia Kardos ${ }^{3}$, Ferenc Rozgonyi ${ }^{3}$ and Pál Herczegh ${ }^{1}$
}

The Journal of Antibiotics (2009) 62, 113-116; doi:10.1038/ja.2008.26; published online 16 January 2009

Keywords: antibacterial; fluoroquinolone; permanent bond; polyethylene glycol; telechelic

$\mathrm{C}_{2}$-symmetric (divalent) biologically active molecules are an extensively studied field, as certain substances possessing a B-linker-B type structure (where B represents a bioactive molecule) have promising biological properties. ${ }^{1}$ The synthesis and investigation of the dimers of the highly antibacterial quinolonecarboxylic acids were also carried out. However, the norfloxacin dimers linked with an alkyl chain, described by Coppel et al., ${ }^{2}$ were very slightly active. Later Kerns et $a .^{3-5}$ synthesized the $\mathrm{C}_{2}$-symmetric and mixed dimers of ciprofloxacin and norfloxacin using 1,4-phenylenebis-methylene and 2-butene-1,4-diyl linkers. These derivatives possessed comparable activity with that of the monomers and, in a few cases, higher MIC values were found against certain drug-resistant strains.

Polyethylene glycol (PEG), a cheap and nontoxic telechelic polymer diol of amphiphilic character is soluble both in water and organic solvents; therefore, it is often used as a carrier for drug molecules.

Bioactive molecules linked covalently to PEG possess favorable pharmacodynamic properties due to high water solubility and lipophilicity of the polymer, and PEGylation usually results in an enhanced biological stability and the products are less immunogenic. The PEGylated drug conjugates are primarily used in a 'releasable' form (that is, in a form linked by means of bondings unstable in a biological milieu).

In contrast, in the permanently bonded form, the drug molecule is attached to the polymer with covalent bondings stable in a biological milieu. The permanently bonded form is also advantageous, as numerous drug molecules introduced to therapy contains PEG in such a linkage. Related compounds are the PEGylated derivative of the bovine adenosyl deaminase enzyme ADAGEN, ${ }^{6}$ the PEGylated L-asparagine-containing ONCASPAR, ${ }^{7}$ PEG-INTRON,${ }^{8}$ which con- tains PEGylated interferon, and NEULASTA ${ }^{9}$ carrying a PEGylated granulocyte-colony stimulating factor. Incorporation of the monofunctional PEG chain(s) to these protein-type bioactive molecules resulted in decreasing immunogenity of the parent compound, as well as in the increase of the circulation half-life time and the stability. There are few reports on permanently bonded drugs, but those compounds exhibit low biological activity. ${ }^{10}$

Ciprofloxacin was encapsulated in PEG-coated, long-circulating sustained-release liposomes. ${ }^{11,12}$ It is to be noted that Carraher et al. ${ }^{13}$ reported the synthesis and biological activity of ciprofloxacin covalently bonded to organotin polymers of $\mathbf{1}$ and $\mathbf{2}$. Norfloxacin was also attached to methacrylate polymers. ${ }^{14}$

The goal of this work was to investigate the antimicrobial effect of the quinolonecarboxylic acid dimers prepared with a PEG linker, and to study the effect of PEGylation on the antibacterial activity.

To investigate the separate effect of the PEGylation and dimerization of $\mathbf{1}$ and $\mathbf{2}$ on the antimicrobial effect, both the mono- and bifunctional PEG derivatives of the antimicrobial agents were prepared.

Monomethoxy-PEG $\left(\mathrm{MW}_{\text {average }}=1132 \mathrm{Da}\right)$ and PEG $\left(\mathrm{MW}_{\text {average }}=\right.$ $1382 \mathrm{Da}$ ) were converted ${ }^{15}$ into the monoamino (3) and diamino (4) derivatives, whose treatment with thiophosgene gave the corresponding mono- and diisothiocyanates $\mathbf{5}$ and $\mathbf{6}$, respectively (Scheme 1).The reaction of $\mathbf{4}$ and $\mathbf{6}$ with ciprofloxacin and norfloxacin under mild conditions (Scheme 1) led to the PEG-conjugates $(\mathbf{7}, \mathbf{8}, \mathbf{9}, \mathbf{1 0})$, whose structures were proved by matrix-assisted laser desorption/ ionization (MALDI) mass spectrometry and NMR spectroscopy. (Figure 1 represents the MALDI-time of flight (TOF) mass spectrum of 6 and 9). Thiourea and its derivatives cannot be hydrolyzed by

${ }^{1}$ Department of Pharmaceutial Chemistry, University of Debrecen, Debrecen, Hungary; ${ }^{2}$ Department of Applied Chemistry, University of Debrecen, Debrecen, Hungary and ${ }^{3}$ Institute of Medicinal Microbiology, Semmelweis University, Budapest, Hungary 


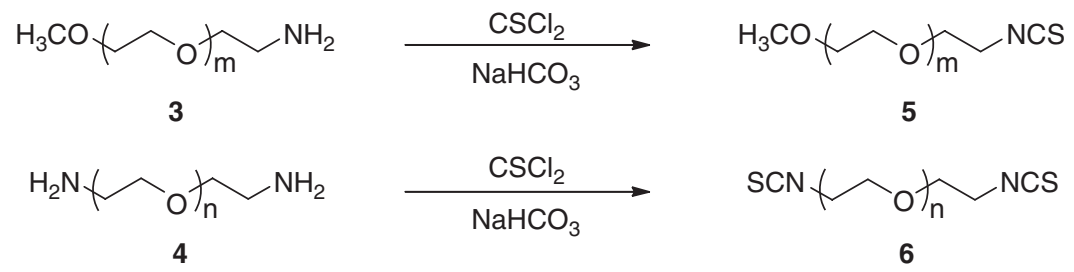

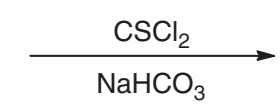<smiles>[R]C1CC1C(=O)NCCOCCOC(C)(C)C(=S)N1CCN(c2cc3c(cc2F)c(=O)c(C(=O)O)cn3[R])CC1</smiles>

$2 \mathrm{R}=-\mathrm{C}_{2} \mathrm{H}_{5}$

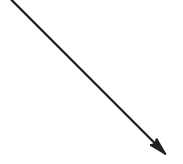<smiles>[R]C1CC1CCOCCNC(=S)N1CCN(c2cc3c(cc2F)c(=O)c(C(=O)O)cn3[R])CC1</smiles>

Scheme 1 Formation of PEG-isothiocyanates and synthesis of PEGylated quinolonecarboxylic acid derivatives.

ureases of different origin ${ }^{16,17}$ or they are inhibitors of these enzymes. ${ }^{18}$ Therefore, the permanently bonded drug conjugates containing a thiourea-linking moiety are expected as stable molecules under biological conditions. Consequently, the prepared permanently bonded drug conjugates do not correspond to a delivery system, but represent original macromolecules carrying bioactive endgroups.

The data in Table 1 show the MIC values of our substances toward several bacterial strains. As PEGylation increases the molecular mass aproximately 5-6 times, the change in the activity expressed in $\mu \mathrm{moll}^{-1}$ is more informative than the concentrations given in $\mu \mathrm{g} \mathrm{ml}^{-1}$.

The PEG conjugates possessed weak activity, or were inactive against the Gram-positive Staphylococci, with the exception of the dimeric ciprofloxacin 9 against strains $\mathbf{a}$ and $\mathbf{b}$ (in $7.5 \mu \mathrm{moll}^{-1}$ ). Nevertheless, 1 and $\mathbf{2}$ were also inefficient toward half of the Grampositive strains investigated. At the same time, against Bacillus subtilis, the ciprofloxacin derivatives $\mathbf{7}$ and $\mathbf{9}$ have similar activity than the parent compounds (in 2.6 and $1.8 \mu \mathrm{mol}$, respectively).

PEGylation emerged with more attractive results in the case of the Gram-negative bacterial strains. The PEG derivatives 7 and 9 had molar MIC values against Escherichia coli, Pseudomonas aeruginosa and Enterobacter cloacae similar to those of ciprofloxacin and norfloxacin, and the norfloxacyl compound $\mathbf{1 0}$ was also reasonably efficient against E. coli (g). PEGylation decreased the activity of norfloxacin more than that of ciprofloxacin. On the other hand, on comparison of the microbial effect of $\mathbf{1}$ and $\mathbf{2}$ with that of the monovalent and dimeric derivatives (i.e., to $\mathbf{7}$ and $\mathbf{9}$, and to $\mathbf{8}$ and 10, respectively) against Gram-negative strains, no significant changes were observed. Consequently, we may conclude that (at least in the case of the MW=1500 PEG) dimerization of $\mathbf{1}$ and $\mathbf{2}$ does not significantly influence the biological activity against Gram negatives.

As permanent covalent PEGylation does not affect the molar MIC values observed for certain microorganisms, it is believed that compounds 7-10 could be sufficient examples for the further investigation of the influence of PEGylation on antimicrobial activity.

In summary, it was observed that bonding of ciprofloxacin and norfloxacin to PEG with a permanent covalent linkage leads to an insignificant decrease in the molar activity of some of the products against certain Gram-negative bacteria. This fact opens the way to the synthesis of another stable polymer-antibiotic chimera, which may have better antimicrobial activity than that of the parent compounds.

\section{EXPERIMENTAL SECTION}

\section{General methods}

Unless otherwise stated, the starting materials and solvents were purchased from commercial sources (Sigma-Aldrich, St Louis, MO, USA or Fluka, Buchs, Switzerland) and used as received. All solvents were distilled before use. $\mathrm{CH}_{2} \mathrm{Cl}_{2}$ was distilled from $\mathrm{P}_{2} \mathrm{O}_{5}$ and stored over $4 \AA$ molecular sieves. Triethylamine was distilled from KOH before use. ${ }^{1} \mathrm{H}$ NMR spectra were recorded at $360.13 \mathrm{MHz}$ 

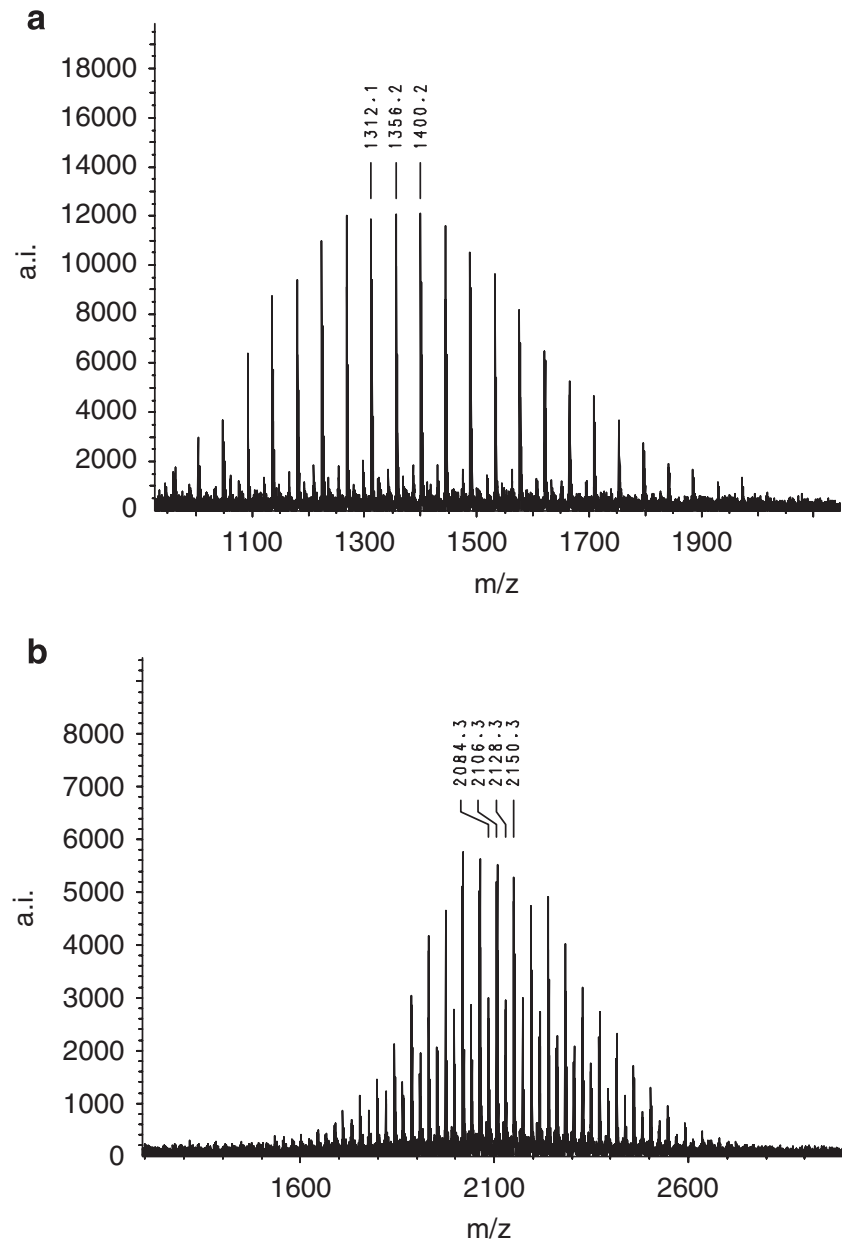

Figure 1 MALDI-TOF mass spectrum of $\mathbf{6}$ (spectrum a) and $\mathbf{9}$ (spectrum b).

with a Bruker WP-360 SY spectrometer, using DMSO- $d_{6}$ as solvent and tetramethylsilane as internal standard. Mass spectra were recorded with a Bruker Biflex-III MALDI-TOF mass spectrometer. For column chromatography, Merck silica gel (Kieselgel 60), 0.063-0.200 mm (70-230 mesh) was used. TLC was performed on Kieselgel $60 \mathrm{~F}_{254}$ (Merck), using $\mathrm{CH}_{2} \mathrm{Cl}_{2}-\mathrm{MeOH}$ solvent system as eluent.

Spots were visualized by irradiation under UV lamp, and/or by spraying with an ammonium-molibdenate/sulfuric acid solution and heating. Evaporations were carried out under diminished pressure at $35-40{ }^{\circ} \mathrm{C}$ (bath temperature).

\section{Monomethoxy-isothiocyanato-PEG (5)}

To a solution of $60 \mathrm{ml}$ of $0.54 \mathrm{M}$ sodium hydrogencarbonate in water, a solution of thiophosgene $(0.520 \mathrm{ml}, 6.08 \mathrm{mmol})$ in dichloromethane $(60 \mathrm{ml})$ was added. The mixture was stirred vigorously and a solution of $3(3.0 \mathrm{~g}, 2.73 \mathrm{mmol})$ in dichloromethane $(100 \mathrm{ml})$ was added dropwise for $1 \mathrm{~h}$. After $15 \mathrm{~min}$, the aqueous phase was extracted with $\mathrm{CH}_{2} \mathrm{Cl}_{2}(2 \times 100 \mathrm{ml})$. Evaporation of the combined organic phases resulted in $2.87 \mathrm{~g}$ of $\mathbf{5}(93 \%)$. The structure and purity were proved by the MALDI spectrum.

MS (MALDI-TOF) $\mathrm{MW}_{\text {average }}=1153.2 \mathrm{Da} \quad(\mathrm{M}+\mathrm{Na})^{+}$. Calculated for $\mathrm{C}_{50} \mathrm{H}_{99} \mathrm{O}_{24} \mathrm{NS}$ 1129.6.

\section{Diisothiocyanato-PEG (6)}

It was obtained from the diamino-PEG with the method applied for $\mathbf{5}$ using 2 equivalents of $\mathrm{CSCl}_{2}$ and $\mathrm{NaHCO}_{3}$. Yield: $92 \%$.
MS (MALDI-TOF) $\mathrm{MW}_{\text {average }}=1356.2 \mathrm{Da} \quad(\mathrm{M}+\mathrm{Na})^{+}$. Calculated for $\mathrm{C}_{58} \mathrm{H}_{112} \mathrm{O}_{27} \mathrm{~N}_{2} \mathrm{~S}_{2}$ 1332.7.

Preparation of thiocarbamoyl-PEG derivatives of 1 and 2 (7-10) Typical procedure (for 9)

$1 \mathrm{HCl}(0.154 \mathrm{~g}, 0.42 \mathrm{mmol})$ and triethylamine $(0.116 \mathrm{ml}, 0.84 \mathrm{mmol})$ were dissolved in dry $\mathrm{CH}_{2} \mathrm{Cl}_{2}(35 \mathrm{ml})$, then $0.201 \mathrm{~g}(0.14 \mathrm{mmol})$ of 6 was added and the mixture was allowed to react for 3 days at room temperature. The product was purified by column chromatography on silica gel using an $85: 15 \mathrm{CH}_{2} \mathrm{Cl}_{2}-$ $\mathrm{MeOH}$ solvent system as eluent. Yield: $67 \mathrm{mg}$ (23\%).

MS (MALDI-TOF) $\quad \mathrm{MW}_{\text {average }}=2106.3 \mathrm{Da} \quad(\mathrm{M}+\mathrm{Na})^{+}, \quad 2128.3 \mathrm{Da}$ $(\mathrm{M}-\mathrm{H}+2 \mathrm{Na})^{+}$. Calculated for $\mathrm{C}_{96} \mathrm{H}_{156} \mathrm{O}_{35} \mathrm{~N}_{8} \mathrm{~S}_{2} \mathrm{~F}_{2}$ 2083.0.

${ }^{1} \mathrm{H}$ NMR $\left(360 \mathrm{MHz}\right.$, DMSO- $\left.d_{6}\right) \delta 8.67(2 \mathrm{H}, \mathrm{s}$, quinolone $\mathrm{CH}), 7.92(2 \mathrm{H}, \mathrm{d}$, $J=13.3$, aromatic), $7.55\left(2 \mathrm{H}, \mathrm{d}, J=7.4\right.$, aromatic), $4.02-4.04\left(4 \mathrm{H}, \mathrm{m},-\mathrm{CH}_{2^{-}}\right.$ $\mathrm{NH}-\mathrm{C}=\mathrm{S}), 3.80-3.86(2 \mathrm{H}, \mathrm{m}$, cyclopropyl $\mathrm{CH}), 3.34-3.71\left(\mathrm{~m}\right.$, polymer $-\mathrm{CH}_{2^{-}}$ $\mathrm{CH}_{2}$-O-, piperazine), $1.22-1.37$ (8H, m, cyclopropyl methylene).

\section{Compound 7}

$1 \mathrm{HCl}(0.089 \mathrm{~g}, 0.24 \mathrm{mmol})$ and triethylamine $(66 \mu \mathrm{l}, 0.84 \mathrm{mmol})$ were dissolved in dry $\mathrm{CH}_{2} \mathrm{Cl}_{2}(35 \mathrm{ml})$, then $0.19 \mathrm{~g}(0.16 \mathrm{mmol})$ of 5 was added and the procedure described for 9 was used. Yield: $55 \mathrm{mg}(23 \%)$.

MS (MALDI-TOF) $\quad \mathrm{MW}_{\text {average }}=1527.6 \mathrm{Da} \quad(\mathrm{M}+\mathrm{Na})^{+}, \quad 1549.6 \mathrm{Da}$ $(\mathrm{M}-\mathrm{H}+2 \mathrm{Na})^{+}$. Calculated for $\mathrm{C}_{69} \mathrm{H}_{121} \mathrm{O}_{28} \mathrm{~N}_{4} \mathrm{SF}$ 1504.8.

${ }^{1} \mathrm{H}$ NMR $\left(360 \mathrm{MHz}\right.$, DMSO- $\left.d_{6}\right) \delta 8.66(1 \mathrm{H}, \mathrm{s}$, quinolone $\mathrm{CH}), 7.91$ ( $1 \mathrm{H}, \mathrm{d}, J=13.3$, aromatic), 7.55 ( $1 \mathrm{H}, \mathrm{d}, J=7.4$, aromatic), $4.02-4.06(2 \mathrm{H}, \mathrm{m}$, $-\mathrm{CH}_{2}-\mathrm{NH}-\mathrm{C}=\mathrm{S}$ ), 3.78-3.88 (1H, m, cyclopropyl $\mathrm{CH}$ ), 3.34-3.71 (m, polymer - $\mathrm{CH}_{2}-\mathrm{CH}_{2}$-O-, piperazine), 3.24 (3H, s, $\left.\mathrm{H}_{3} \mathrm{C}-\mathrm{O}-\mathrm{CH}_{2}-\mathrm{CH}_{2}-\mathrm{O}-\right)$, $1.22-1.35$ (4H, m, cyclopropyl methylene).

\section{Compound 8}

$5(0.196 \mathrm{~g}, 0.17 \mathrm{mmol})$ was dissolved in dry $\mathrm{CH}_{2} \mathrm{Cl}_{2}(50 \mathrm{ml})$ and $2(0.081 \mathrm{~g}$, $0.25 \mathrm{mmol}$ ) was added. Using the general method, $48 \mathrm{mg}$ of 8 was resulted (20\%).

MS (MALDI-TOF) $\quad \mathrm{MW}_{\text {average }}=1428.1 \mathrm{Da} \quad(\mathrm{M}+\mathrm{Na})^{+}, \quad 1450.1 \mathrm{Da}$ $(\mathrm{M}-\mathrm{H}+2 \mathrm{Na})^{+}$. Calculated for $\mathrm{C}_{64} \mathrm{H}_{113} \mathrm{O}_{26} \mathrm{~N}_{4} \mathrm{SF}$ 1404.7.

${ }^{1} \mathrm{H}$ NMR $\left(360 \mathrm{MHz}\right.$, DMSO- $\left.d_{6}\right) \delta 8.95(1 \mathrm{H}, \mathrm{s}$, quinolone $\mathrm{CH}), 7.94$ (1H, d, $J=13.3$, aromatic), 7.18 ( $1 \mathrm{H}, \mathrm{d}, J=7.4$, aromatic), 4.59 (2H, q, $J=7.1$, $\left.\mathrm{H}_{3} \mathrm{C}-\mathrm{CH}_{2}-\mathrm{N}\right), 4.00-4.06\left(2 \mathrm{H}, \mathrm{m},-\mathrm{CH}_{2}-\mathrm{NH}-\mathrm{C}=\mathrm{S}\right), 3.27-3.71$ (m, polymer - $\mathrm{CH}_{2}-\mathrm{CH}_{2}-\mathrm{O}-$, piperazine), $3.24\left(3 \mathrm{H}, \mathrm{s}, \mathrm{H}_{3} \mathrm{C}-\mathrm{O}-\mathrm{CH}_{2}-\mathrm{CH}_{2}-\mathrm{O}-\right), 1.42(3 \mathrm{H}, \mathrm{t}$, $\left.\mathrm{CH}_{3}-\mathrm{CH}_{2}-\mathrm{N}\right)$.

\section{Compound 10}

$6(0.196 \mathrm{~g}, 0.13 \mathrm{mmol})$ was dissolved in dry $\mathrm{CH}_{2} \mathrm{Cl}_{2}(50 \mathrm{ml})$ and $2(0.118 \mathrm{~g}$, $0.37 \mathrm{mmol}$ ) was added, and the reaction mixture was stirred for 3 days at room temperature. The product was purified by column chromatography on silica gel using a 85:15 $\mathrm{CH}_{2} \mathrm{Cl}_{2}-\mathrm{MeOH}$ solvent system as eluent. Yield: $48 \mathrm{mg}(18 \%)$.

MS (MALDI-TOF) $\quad \mathrm{MW}_{\text {average }}=2082.5 \mathrm{Da} \quad(\mathrm{M}+\mathrm{Na})^{+}, \quad 2104.5 \mathrm{Da}$ $(\mathrm{M}-\mathrm{H}+2 \mathrm{Na})^{+}$. Calculated for $\mathrm{C}_{94} \mathrm{H}_{156} \mathrm{O}_{35} \mathrm{~N}_{8} \mathrm{~S}_{2} \mathrm{~F}_{2}$ 2059.0.

${ }^{1} \mathrm{H}$ NMR $\left(360 \mathrm{MHz}\right.$, DMSO- $\left.d_{6}\right) \delta 8.95(1 \mathrm{H}, \mathrm{s}$, quinolone $\mathrm{CH}), 7.94(1 \mathrm{H}, \mathrm{d}$, $J=13.3$, aromatic), $7.18(1 \mathrm{H}, \mathrm{d}, J=7.4$, aromatic $), 4.59\left(4 \mathrm{H}, \mathrm{q}, J=7.1, \mathrm{H}_{3} \mathrm{C}-\right.$ $\left.\mathrm{CH}_{2}-\mathrm{N}\right), 4.02-4.06\left(4 \mathrm{H}, \mathrm{m},-\mathrm{CH}_{2}-\mathrm{NH}-\mathrm{C}=\mathrm{S}\right), 3.27-3.71\left(\mathrm{~m}\right.$, polymer $-\mathrm{CH}_{2}-$ $\mathrm{CH}_{2}-\mathrm{O}-$, piperazine), $1.42\left(3 \mathrm{H}, \mathrm{t}, \mathrm{CH}_{3}-\mathrm{CH}_{2}-\mathrm{N}\right)$

\section{Biological assays}

The efficacy of the prepared antimicrobials was determined with the broth microdilution method according to the NCCLS guideline. ${ }^{19}$ Bacterial strains were grown on $5 \%$ bovine blood agar plates at $35^{\circ} \mathrm{C}$ overnight. Appropriate numbers of colonies were suspended in physiological saline to reach the density of 0.5 McFarland for inoculation.

Stock solutions of different concentrations of the substances were prepared in either distilled water or $\mathrm{H}_{2} \mathrm{O}$ and methanol (1:1) or $\mathrm{H}_{2} \mathrm{O}$ and DMSO (1:1), respectively, depending on the solubility of the given preparation. These were twofold serially diluted from 256 to $0.5 \mu \mathrm{g} \mathrm{ml}^{-1}$ in cation-adjusted MuellerHinton broth, then $100 \mu \mathrm{l}$ of each dilution was transferred into microplate holes. Inoculation was carried out with $10 \mu \mathrm{l}$ of each bacterial suspension. 
Table 1 MICs of quinolonecarboxylic acid derivatives $\left(\mu \mathrm{mol}^{-1}\right)$

\begin{tabular}{|c|c|c|c|c|c|c|}
\hline \multirow{2}{*}{ Test microorganismus } & \multicolumn{6}{|c|}{ MIC $\left(\mu \mathrm{mol} /^{-1}\right)$} \\
\hline & $\begin{array}{c}\text { Ciprofloxacin } \\
\text { hydrochloride } 1\end{array}$ & Norfloxacin 2 & $\begin{array}{c}\text { Mono-ciprofloxacyl- } \\
\text { PEG } 7\end{array}$ & $\begin{array}{c}\text { Mono-norfloxacyl- } \\
\text { PEG } 8\end{array}$ & $\begin{array}{c}\text { Bis-ciprofloxacyl- } \\
\text { PEG } 9\end{array}$ & $\begin{array}{l}\text { Bis-norfloxacyl- } \\
\text { PEG } 10\end{array}$ \\
\hline Staphylococcus aureus ${ }^{\mathrm{a}}$ & 1.3 & 6.2 & 42.2 & $>166.4$ & 7.5 & $>125.4$ \\
\hline Staphylococcus aureus ${ }^{\mathrm{b}}$ & 1.3 & 6.2 & 84.4 & $>166.4$ & 7.5 & $>125.4$ \\
\hline Staphylococcus aureus ${ }^{c}$ & $>696.3$ & $>801.2$ & $>168.9$ & $>166.4$ & $>120.3$ & $>125.4$ \\
\hline Staphylococcus epidermidis ${ }^{f}$ & $>696.3$ & $>801.2$ & $>168.9$ & $>166.4$ & $>120.3$ & $>125.4$ \\
\hline Escherichia colis & 1.3 & 1.5 & 0.6 & 10.4 & 3.7 & 3.9 \\
\hline Pseudomonas aeruginosa ${ }^{\mathrm{h}}$ & 1.3 & 1.5 & 10.5 & $>166.4$ & 3.7 & 62.7 \\
\hline Klebsiellai & 174.0 & 801.2 & $>168.9$ & $>166.4$ & $>120.3$ & $>125.4$ \\
\hline Bacillus subtilis ${ }^{\mathrm{j}}$ & 1.3 & 1.5 & 2.6 & 20.8 & 1.8 & 15.6 \\
\hline Enterobacter cloacae ${ }^{k}$ & 1.3 & 1.5 & 2.6 & 41.6 & 1.8 & 31.3 \\
\hline
\end{tabular}

aATC 29213 (methicillin susceptible)

bATTC 33591 (methicillin resistant).

c13797 (methicillin, ciprofloxacin resistant).

d13654 (ciprofloxacin resistant).

eATTC 25299 (methicillin susceptible).

${ }^{f} 12333$ (methicillin resistant, mecA gene positive).

gATTC 25992.

${ }^{\mathrm{h} N C T C} 10006$

i4660 (2005) (ESBL)

jATCC 6633.

k11213 (2005).

'ATCC 6018.

Incubation was performed at $35^{\circ} \mathrm{C}$ for $18 \mathrm{~h}$ and determination of the MIC was made with naked eyes on a mirror.

Solvents were also tested for inhibition of bacterial growth, and none of them exerted bacteriostatic effect at the concentration used.

\section{ACKNOWLEDGEMENTS}

This work was supported by the Hungarian Academy of Sciences and the National Scientific Research Found Grants no.: OTKA T042512, T046186, T046744 and RET-06/2004.

1 Bérubé, G. Natural and synthetic biologically active dimeric molecules: anticancer agents, anti-HIV agents, steroid derivatives and opioid antagonists. Curr. Med. Chem. 13, 131-154 (2006).

2 Coppel, R., Deady, L., Loria, P., Olden, D. \& Turnidge, J. Synthesis and antibacterial activity of some bisquinones. Aust. J. Chem. 49, 255-259 (1996).

3 Kerns, R. J. et al. Piperazinyl-linked fluoroquinolone dimers possessing potent antibacterial activity against drug-resistant strains of Staphylococcus aureus. Bioorg. Med. Chem. Lett. 13, 1745-1749 (2003).

4 Kerns, R. J. et al. Structural requirements of piperazinyl-linked fluoroquinolone dimers for activity against drug-resistant strains of Staphylococcus aureus. Bioorg. Med. Chem. Lett. 13, 2109-2112 (2003).

5 Kerns, R. J., Rybak, M. J. \& Cheung, C. M. Susceptibility studies of piperazinyl-crosslinked fluoroquinolone dimers against test strains of Gram-positive and Gram-negative bacteria. Diagn. Microbiol. Infect. Dis. 54, 305-310 (2006).

6 Hershfield, M. S. Adenosine deaminiase deficiency: clinical expression, molecular basis, and therapy. Semin. Hematol. 35, 291-298 (1998).

7 Kurtzberg, J. Asparaginase. in Cancer Medicine. 4th edn (eds Holland Jr J.F., Bast Jr R.C., Morton D.L., Frei III E., Kufe D.W., \& Weichselbaum R.R.) 1027 (Lippinscott Williams and Wilkins, V.I, Section XVI, Chemotherapeutic Agents, Baltimore, MD, 1997).

8 Grace, M. et al. Structural and biologic characterization of pegylated recombinant IFN- alpha 2b. IFN Cytokine Res. 21, 1103-1115 (2001).
9 Holmes, F. A. et al. Blinded, randomized, multicenter study to evaluate single administration pegfilgrastim once per cycle versus daily filgrastim as an adjunct to chemotherapy in patients with high-risk stage II or stage III/IV breast cancer. J. Clin. Oncol. 20, 727-731 (2002).

10 Greenwald, R. B., Pendri, A. \& Bolikal, D. Highly water soluble taxol derivatives: 7-polyethylene glycol carbamates and carbonates. J. Org. Chem. 60, 331-336 (1995).

11 Bakker-Woudenberg, I. J. M., ten Kate, M. T., Guo, L., Working, P. \& Mouton, J. W. Improved efficacy of ciprofloxacin administered in polyethylene glycol-coated liposomes for treatment of Klebsiella pneumoniae pneumonia in rats. Antimicrob. Agents Chemother. 45, 1487-1492 (2001).

12 Bakker-Woudenberg, I. J. M., ten Kate, M. T., Guo, L., Working, P. \& Mouton, J. W. Ciprofloxacin in polyethylene glycol-coated liposomes: efficacy in rat models of acute or chronic Pseudomonas aeruginosa infection. Antimicrob. Agents Chemother. 46, 2575-2581 (2002).

13 Naoshima, Y., Nagao, K., Carraher, C. E., Zhao, A. \& Siegmann-Louda, D. W. Bacterial activity of organotin polymers derived from ciprofloxacin, cephalexin, norfloxacin, and acyclovir. Polym. Mater. Sci. Eng. 90, 534-536 (2004).

14 Dizman, A. \& Mathias, L. J. Synthesis, characterization, and antibacterial activities of novel methacrylate polymers containing norfloxacin. Biomacromolecules 6, 514-520 (2005).

15 Mongondry, P., Bonnans-Plaisance, C., Jean, M. \& Tassin, J. F. Mild synthesis of aminopoly(ethylene glycol)s. application to steric stabilization of clays. Macromol. Rapid Commun. 24, 681-685 (2003).

16 Dixon, N. E., Riddles, P. W., Gazzola, C., Blakeley, R. L. \& Zerner, B. Jack bean urease (EC 3.5.1.5). V. On the mechanism of action of urease on urea, formamide, acetamide, $\mathrm{N}$-methylurea, and related compounds. Can. J. Biochem. 58, 1335-1344 (1980).

17 Clemens, A. L., Lee, B.-Y. \& Horwitz, M. A. Purification, characterization, and genetic analysis of Mycobacterium tuberculosis urease, a potentially critical determinant of host- pathogen interaction. J. Bacteriol. 177, 5644-5652 (1995).

18 Nagata, K., Satoh, H., Iwahi, T., Shimoyama, T. \& Tamura, T. Potent inhibitory action of the gastric proton pump inhibitor lansoprazole against urease activity of Helicobacter pylori: unique action selective for $H$. pylori cells. Antimicrob. Agents Chemother. 37, 769-774 (1993).

19 National Committee for Clinical Laboratory Standards. Performance Standards for Antimicrobial Susceptibility Testing. 12th Informational Supplement M100 - S12. (NCCLS, Wayne, PA, USA, 2002). 